\title{
Geothermal reservoir characteristics of Meso- and Cenozoic sedimentary rocks of Budapest (Hungary)
}

\section{Geothermische Reservoireigenschaften meso- und känozoischer Sedimentgesteine von Budapest (Ungarn)}

\section{Annette E. Götz ${ }^{1}$, Ákos Török² Ingo Sass $^{3}$}

${ }^{1}$ University of Pretoria, Department of Geology, Private Bag X20, 0028 Pretoria, South Africa, annette.goetz@up.ac.za

${ }^{2}$ Budapest University of Technology and Economics, Department of Construction Materials and Engineering Geology, Müegyetem rkp. 3, H-1111 Budapest, Hungary, torokakos@mail.bme.hu

${ }^{3}$ Technische Universität Darmstadt, Institute of Applied Geosciences, Chair of Geothermal Science and Technology, Schnittspahnstr. 9, D-64287 Darmstadt, Germany, sass@geo.tu-darmstadt.de

\begin{abstract}
The characterization of deep geothermal reservoirs of sedimentary basins is supported by outcrop analogue studies since reservoir characteristics are strongly related to the sedimentary facies and thus influence the basic direction of geothermal field development and applied technology. Permeability and thermal conductivity are key parameters in geothermal reservoir characterization and the data gained from outcrop samples serve to understand the reservoir system.

New thermophysical data from the Meso- and Cenozoic sedimentary rocks of Budapest include carbonates and siliciclastics of Triassic, Eocene, Oligocene and Miocene age as well as Pleistocene travertine, exposed on the western side of the river Danube in the Buda Hills. Field and laboratory analyses revealed distinct horizons of different geothermal potential and thus, enable to identify and interpret corresponding exploration target horizons in geothermal prone depths in the Budapest region as well as in sub-basins of the Pannonian Basins System exhibiting geothermal anomalies.
\end{abstract}


Kurzfassung: Aufschlussanalogstudien dienen der Charakterisierung tiefer geothermischer Reservoire in Sedimentbecken, da die

Reservoireigenschaften der Gesteine sehr stark an die Sedimentfazies gebunden sind und damit die unterschiedliche geothermische Erschließung bestimmen. Permeabilität und Wärmeleitfähigkeit stellen die wesentlichen Parameter der geothermischen Reservoircharakterisierung da und die Daten, die von Aufschlussproben gewonnen werden können dienen dem besseren Verständnis des gesamten Reservoirsystems.

Die aktuelle Studie liefert neue thermophysikalische Daten meso- und känozoischer Sedimentgesteine aus Aufschlussanalogstudien im westlichen Stadtgebiet von Budapest (Buda). Die beprobte Sedimentabfolge beinhaltet Karbonate und Siliziklastika triassischen und tertiären Alters sowie pleistozäne Travertine. Geländearbeiten und Laboranalysen ermöglichten die Identifizierung unterschiedlicher Reservoirgesteine, welche in den verschiedenen Teilbecken des Pannonischen Beckensystems aufgrund der entsprechenden Teufe und Temperaturen für die geothermische Nutzung von großer Bedeutung sind.

Keywords: Deep geothermal systems, thermophysical rock properties, thermofacies, Buda Hills, Hungary

Schlüsselwörter: Tiefe Geothermie, thermophysikalische Gesteinseigenschaften, Thermofazies, Buda Berge, Ungarn

\section{Introduction}

The detailed knowledge of sedimentary features from microscopic to regional scales is regarded as crucial in reservoir characterization and prediction of deep geothermal systems. Generally, in the early stages of geothermal reservoir exploration, characterization of the reservoir is accomplished by evaluation of possibly available drilling data and seismic surveys. However, for reservoir prognosis, the main geothermal parameters such as permeability, thermal conductivity, and reservoir heat flow have to be quantified with respect to an integrated structural 3D 
model of the subsurface. Outcrop analogue studies serve to predict such subsurface petrophysical and thermophysical properties (Aretz et al. 2013, Homuth et al. 2014), and based on detailed facies analysis, the geothermal exploration concept becomes more precise and descriptive.

Here, we present data from the Buda Hills of the Budapest municipal area which serve to quantify the geothermal potential of Meso- and Cenozoic rocks from outcrop analogues and may contribute to establish integrated structural 3D reservoir models of the Hungarian sub-basins of the Pannonian Basins System.

\section{Materials and methods}

The Meso- and Cenozoic sedimentary succession of Budapest is built up by carbonates and clastic sediments of Triassic, Eocene, Oligocene and Miocene age as well as Pleistocene travertine, exposed in the Buda Hills on the western side of the river Danube. The Buda Hills represent the easternmost part of the Transdanubian Range (Fig. 1) built up by sedimentary rocks that are located in geothermal prone depth in the different Hungarian sub-basins of the Pannonian Basins System.

All lithologies were sampled to gain representative data from all rock types. The measurements of the petro- and thermophysical properties were conducted on oven dried plug samples (35 mm length and diameter) drilled from the rock samples. Separate measurements of skeletal density (Helium Pycnometer AccuPyc 1330) and envelope density (DryFlo Pycnometer GeoPyc 1360) enabled the calculation of porosity. Permeability measurements were carried out using a gas mini-permeameter which utilizes pressured differential air flow through a plug sample. Permeability is calculated by incorporating the injection pressure $p_{i}$, the mass flow rate $M_{i}$ and the ambient atmospheric pressure $p_{a}$ (Goggin et al. 1988). Thermal conductivities of the different rock types were measured by an optical scanning device applying the method after Popov et al. (1999). The investigated rocks were classified applying the thermofacies concept introduced by Sass \& Götz (2012). 


\section{Geological setting, stratigraphy and lithotypes}

The Pannonian Basin belongs to the key areas in central Europe with a high geothermal energy potential (Dövényi et al. 2002). Lithospheric extension during the Miocene created the complex basin system characterized by high geothermal gradients $\left(4-8^{\circ} \mathrm{C} / 100 \mathrm{~m}\right)$.

The formation of this basin system upon the Palaeozoic-Mesozoic basement and the remnants of the older Palaeogene basins started in the Early Miocene (Late Egerian-Eggenburgian), thus representing a Neogene-Quaternary basin-fill history (for review see Rasser et al. 2008, Nagymarosy \& Hámor 2012). The most complete successions are found in tectonically controlled sub-basins (Horváth \& Tari 1999) with a maximum thickness of $7000 \mathrm{~m}$ and even more (Békés and Makó sub-basins). Continuing deposition is documented by recent fluviatile and eolic sedimentation. The present-day Pannonian Basin has an extremely thin continental crust and lithosphere compared to its surrounding areas (Royden 1988) and high values of heat flux (between $80-110 \mathrm{~mW} / \mathrm{m}^{2}$ ) were measured in the interior sub-basins (Dövényi \& Horváth 1988). Against the background of this basin history, two settings have to be considered with respect to exploitation of geothermal energy: (1) the Palaeo-Mesozoic faulted basement and (2) the Neogene basin fill.

In the study area in Budapest both Mesozoic carbonates and Neogene sedimentary rocks are represented forming a complex system of geothermal reservoirs. The sedimentary succession of the Buda Hills starts with Triassic carbonates (Fig. 2). Sediments of the Jurassic, Cretaceous and Palaeocene are completely eroded. The Cenozoic succession begins with coastal marine deposits of Eocene age, and is followed by a deepeningupward carbonate sequence. In the Oligocene coastal sandstones and conglomerates and basinal siltstones and clays were formed. The Miocene period is characterized by various types of shallow marine, fluvial to terrestrial sediments (Nagymarosy \& Hámor 2012). Pleistocene travertines are the youngest sediments studied.

Triassic Dolomites and Limestones 
The Buda Hills, representing the easternmost part of the Transdanubian Range, expose Middle to Upper Triassic platform carbonates including the Upper Anisian to lowermost Carnian Budaörs Dolomite, the Carnian Födolomit (Hauptdolomit), the Norian to Rhaetian Dachstein Limestone and Upper Triassic cherty limestones and dolomites (Mátyáshegy Limestone) of basinal facies (Haas \& Budai 1999).

\section{Eocene Limestone and Marl}

The Eocene succession of the Buda Hills (Kázmér 1985) includes Priabonian shallow marine limestones (Szépvölgy Limestone Formation) rich in foraminifera (e.g., Nummulites, Discocyclina) and Lithothamnium overlain by calcareous marls of outer ramp facies (Buda Marl Formation).

Globigerina wackestones are characteristic of the outer ramp setting, while Bryozoan pack-/floatstones indicate a shallower storm-dominated setting (Kleb et al. 1993).

\section{Oligocene Sandstone and Clay}

In the Buda Hills, the Oligocene is represented by medium- to coarse-grained sandstones and conglomerates (Hárshegy Sandstone) displaying a great variation in colour from yellowish-brown to dark red. These coastal deposits are a stratigraphic equivalent of pelagic clays (Kiscell Clay Formation), characterized by sandstone intercalations in the lower part as well as locally turbiditic layers (Nagymarosy 1987).

In some parts of the Buda Hills, the Hárshegy Sandstone shows a discordant contact to the underlying Late Triassic Dachstein Limestone. In other parts it overlies an up to $100 \mathrm{~m}$ thick anoxic black shale unit (Tard Clay Formation), representing a hydrocarbon source rock. Upsection, coastal deposits are represented by the Egerian Törökbálint Sandstone Formation.

\section{Miocene Sandstone and Limestone}

In the Budapest region, coastal sandstones of Early Miocene age are represented by the Pecten-bearing Budafok Sandstone Formation. Middle and Late Miocene deposits are characterized by shallow-water carbonates. The Badenian Leitha Limestone Formation is built up by porous algal 
limestones, calcarenites, and sandy limestones with a diverse mollusk fauna. Fine- to coarse-grained oolitic and bioclastic limestones are characteristic of the Sarmatian Tinnye Limestone Formation (Nagymarosy \& Hámor 2012). The major fabric constituents of the most common lithotype, the oolitic limestone, comprises well to moderately rounded calcitic ooids and visible but evenly scattered small pores of 0.1 to 1 mmsize. Microscopic analyses revealed that the carbonate constituents from a sedimentological point of view are not ooids but micrite-coated grains, i.e. micro-oncoids (Török 2002). The bioclastic lithotype is characterised by a grainstone fabric containing gastropods (Cerithium) and other carbonate constituents such as oncoids, shells and intraclasts.

\section{Travertine}

Most Hungarian travertines were deposited from springs in lacustrine environments during the Pleistocene (Török 2003, Jámbor 2012). A great variety of microfacies types were described from the Buda Castle Hill (Török 2003) and from the Budakalász area (Kele et al. 2003) distinguishing two main lithotypes: a) laminated porous travertine and b) less porous massive travertine (Török 2003, Török \& Vásárhelyi 2010).

Due to the wide variety of sedimentary facies types exposed in the Buda Hills, the study area is well suited to test the thermofacies concept introduced by Sass \& Götz (2012) as exploration tool for deep geothermal reservoirs linked to sedimentary basins.

\section{Petrophysical and thermophysical rock properties}

Different lithologies, including very dense limestones to highly porous ones, dolomites, sandstones and clays, were studied. Selected physical parameters of these sedimentary rocks are given in Table 1. Thermophysical rock properties are displayed in Table 2.

The Triassic carbonates (Hauptdolomit, Budaörs Dolomite, Mátyáshegy Limestone) have values of thermal conductivity in the range of 1,9 to 3,5 $\mathrm{W} /(\mathrm{m} \cdot \mathrm{K})$. Matrix permeabilities measured with a gas permeameter span in the range of $10^{-13}$ to $10^{-15} \mathrm{~m}^{2}$ (Fig. 3). Additionally, these carbonates are 
strongly fractured and show a different degree of karstification increasing the fluid migration. The formation permeability will be strongly enhanced on a reservoir scale. Thus, hydrothermal exploration of such carbonate reservoirs in geothermal prone depths of about $5 \mathrm{~km}$ known from the Zala and Danube basins of W Hungary (western part of the Transdanubian Range and Little Plain) is seen very promising.

Eocene marls show a medium range of thermal conductivity with values of 2,0 to $2,5 \mathrm{~W} /(\mathrm{m} \cdot \mathrm{K})$ and low matrix permeabilities $\left(10^{-15}\right.$ to $\left.10^{-16} \mathrm{~m}^{2}\right)$. The low permeability can be significantly enhanced by fractures and fissures. The tectonical fracturing was followed by thermal dissolution related to upwelling fluids and the formation of cave size cavities (Leél-Össy 1995) and is well documented in outcrops and in core drillings (Kleb et al. 1993).

Oligocene sandstones (Hárshegy Sandstone) show relatively low porosities (Table 1). The Oligocene clay (Kiscell Clay) represents the bathyal counterpart with high clay and moderate silt content (Nagymarosy \& Hámor 2012) and is characterized by a very low permeability.

Clastic sediments of Palaeogene and Neogene age (Fig. 3) are grouped into impermeable and low heat conducting clays (e.g., Kiscell Clay), and permeable, high heat conducting sandstones (e.g., Hárshegy Sandstone). Thus, hydrothermal exploration of permeable sandstone reservoirs in geothermal prone depths known from different sub-basins in Hungary (e.g., Central Great Plain) is also seen very promising.

Miocene bioclastic limestones (e.g, Tinnye Limestone) reveal low values of thermal conductivity in the range of 0,9 to $1,5 \mathrm{~W} /(\mathrm{m} \cdot \mathrm{K})$. On the other hand, they are characterized by high permeabilities $\left(10^{-12}\right.$ to $\left.10^{-13} \mathrm{~m}^{2}\right)$. Thus, auto-convective thermal water circulation is expected here. Depending on their occurrence in the deep subsurface, they might be considered as reservoir rocks. Direct heat use with laminar flow conditions in the reservoir formation and with no need for artificial stimulation is reasonable. Also the reinjection of the thermal water after heat extraction will be very feasible regarding these parameters. The hydrogeological prerequisites are not discussed in this paper.

Travertines show a medium range of thermal conductivity with values between 2,4 and $2,6 \mathrm{~W} /(\mathrm{m} \cdot \mathrm{K})$ and high permeabilities up to $10^{-11} \mathrm{~m}^{2}($ Fig. $3)$. Travertines and Eocene marls are not considered as deep geothermal reservoir rocks: travertines due to their occurrence in the shallow subsurface (low temperature), and marls due to their low permeabilities. 


\section{Discussion}

The general geothermal potential of Hungary, based on temperature data from over 3000 oil and gas boreholes, was discussed and summarized by Dövényi et al. (2002) highlighting the medium to high enthalpy areas in western and southeastern Hungary. In both areas the Mesozoic basement is at depth of $3000-4000 \mathrm{~m}$ (i.e. $150-200{ }^{\circ} \mathrm{C}$ ) and located in the vicinity of major fault zones.

The Mesozoic basement of western Hungary is dominated by limestones and dolomites (Zala and Danube basins) with an effective porosity of 1$3 \%$ and permeabilities up to $100 \mathrm{mD}$ (ca. $1 \times 10^{-11} \mathrm{~m}^{2}$ ), calculated from flow rate measurements during borehole tests (Dövényi et al. 2002).

In the Great Plain the effective porosity of Tertiary (Neogene) sandstones, mainly built up by delta-plain deposits overlying the Meso- and Palaeozoic basement, decreases with depth, but the clastic succession retains remarkable porosity even at depths of 2500-3000 m. The permeability is $400-500 \mathrm{mD}\left(\mathrm{ca} .4-5 \times 10^{-11} \mathrm{~m}^{2}\right)$ on average, with extreme values of 100 and $800 \mathrm{mD}$ (ca. $8 \times 10^{-11} \mathrm{~m}^{2}$ ), at a depth of $2500 \mathrm{~m}$ and close to the subsurface, respectively (Dövényi et al. 2002).

The here presented thermophysical rock properties of the sedimentary succession exposed in the Buda Hills (Fig. 2) clearly identify two main target horizons for future utilization of deep geothermal reservoirs: (1) Triassic fractured and karstic dolomites and partly karstic limestones, and (2) Tertiary permeable sandstones. Both potential reservoir rock types are widespread in the sub-basins of the Pannonian Basins System exhibiting geothermal anomalies, e.g. Great Plain, Zala and Danube basins, Little Plain (Haas, 2001, 2012; Fig. 1) and are thus very promising exploration targets with respect to hydrothermal power generation utilizing geothermal energy of deep sedimentary basins.

Applying the thermofacies concept of Sass \& Götz (2012), permeable sandstones of the Tertiary basin fill (Hárshegy Sandstone; Fig. 3) can be directly utilized as hydrothermal systems, whereas low permeable Triassic carbonates (Hauptdolomit, Budaörs Dolomite, Mátyáshegy Limestone; Fig. 3) might be characterized as hydrothermal and transitional (stimulated) systems, resp. depending on the degree of fracturing and karstification. Due to the high fracture porosity and the well developed and interconnected fracture system and cavity network in the Buda Hills (Esteban et al. 2009), this area is well suited for hydrothermal systems. 
Comparing permeability data gained from outcrop samples in the present study and those calculated from borehole measurements (Dövényi et al. 2002), shows the value of outcrop analogue studies to be applied to subsurface characterization and interpretation of geothermal reservoirs. Data from outcrops match the reservoir conditions quite well and thus lead to a conservative estimation of the reservoir utilization. By adding information on secondary porosities (Moench 1984, Şen 2002), karstification (Esteban et al. 2009, Goldscheider et al. 2011), and the distinct stress field (Smith \& Davies 2006) higher reservoir capacities can be inferred. Additionally, a database including all thermophysical rock properties with each parameter measured on the same samples (Fig. 3) is an important base to establish integrated structural 3D reservoir models of the Hungarian subbasins of the Pannonian Basins System.

\section{Conclusions}

A first assessment of the geothermal potential of the Pannonian Basin presented by Dövényi et al. (2002) did not include measured thermophysical data from identified target formations. However, thermophysical rock properties are crucial to assess the potential of a distinct geothermal reservoir rock formation. Outcrop analogue studies serve to establish a sufficient database to characterize rocks of a corresponding deep geothermal reservoir

in regions exhibiting geothermal anomalies. The here presented data enable to (1) identify and interpret exploration target horizons in the Budapest region as well as in other areas of the Transdanubian Range, (2) are important attributes for reservoir modelling and thus contribute to establish integrated structural 3D reservoir models for a reliable reservoir prognosis, and (3) lead to a first assessment of enhanced geothermal system needs, and on sustainable reservoir utilization.

\section{Acknowledgements}

The constructive comments of two anonymous reviewers are gratefully acknowledged. 


\section{References}

Aretz, A., Bär, K. \& Sass, I. (2013): Charakterisierung des geothermischen Reservoirpotentials des Permokarbons in Hessen und RheinlandPfalz - thermophysikalische und hydraulische Gesteinskennwerte. - Swiss Bulletin for Applied Geology: 18/1, 33-41. SFIG/GSGI.

Dövényi, P., Horváth, F. \& Drahos, D. (2002): Hungary. - In: Hurter, S. \& Haenel, R. (eds): Atlas of Geothermal Resources in Europe. Publ. No. EUR 17811 of the European Commission: 36-38, P1. 29-35.

Dövényi, P. \& Horváth, F. (1988): A review of temperature, thermal conductivity, and heat flow data for the Pannonian Basin. - In: Royden, L. \& Horváth, F. (eds): The Pannonian Basin - a study in basin evolution. American Association of Petroleum Geologists, Memoir: 45, 195233, Tulsa (AAPG).

Esteban, M., Budai, T., Juhász, E. \& Lapointe, P. (2009): Alteration of Triassic carbonates in the Buda Mountains - a hydrothermal model. Central European Geology: 52, 1-29, Budapest (Akad. Kiadó).

Goggin, D.J., Thrasher, R.L. \& Lake, L.W. (1988): A theoretical and experimental analysis of minipermeameter response including gas slippage and high velocity flow effects. - In Situ: 12, 79-116, Paris (CNRS).

Goldscheider, N., Mádl-Szőnyi, J., Erőss, A. \& Schill, E. (2011): Review: Thermal water resources in carbonate rock aquifers. - Hydrogeology Journal: 18, 1303-1318, Berlin (Springer). 
Görög, P. (2007a): Characterization and the mechanical properties of the Eocene Buda Marl. - Central European Geology: 50(3), 241-258, Budapest (Akad. Kiadó).

Görög, P. (2007b): Engineering geologic properties of the Oligocene Kiscell Clay. - Central European Geology: 50(4), 13-329, Budapest (Akad. Kiadó).

Haas, J. (Ed.) (2001): Geology of Hungary: 317 p., Budapest (Eötvös University Press).

Haas, J. (Ed.) (2012): Geology of Hungary. - Regional Geology Reviews: 365 pp., Berlin (Springer).

Haas, J. \& Budai, T. (1999): Triassic sequence stratigraphy of the Transdanubian Range (Hungary). - Geologica Carpathica: 50(6), 495-475, Bratislava (Slovak Academy of Sciences).

Hajnal, G. (2002): New method of calculating water balance for the Castle Hill of Buda. - Acta Geologica Hungarica: 45, 385-402, Budapest (Akad. Kiadó).

Homuth, S., Götz, A.E. \& Sass, I. (2014): Facies relation and depth dependency of thermo-physical rock parameters of the Upper Jurassic geothermal carbonate reservoirs of the Molasse Basin. ZDGG. [in review] 
Horváth, F. \& Tari, G. (1999): IBS Pannonian Basin project: a review of the main results and their bearings on hydrocarbon exploration. - In: Durand, B. et al. (eds): The Mediterranean Basins: Tertiary extension within the Alpine Orogen. Geological Society, London, Special Publications: 156, 195-213.

Jámbor, Á. (2012): Quaternary Evolution. - In: Haas, J. (ed.): Geology of Hungary. - Regional Geology Reviews: 201-213, Berlin (Springer).

Kázmér, M. (1985): Microfacies pattern of the Upper Eocene limestones at Budapest, Hungary. - Annales Universitatis Scientiarum Budapestinensis (ELTE), Section Geology: 25, 139-152, Budapest (ELTE).

Moench, A.F. (1984): Double-porosity models for a fissured groundwater reservoir with fracture skin. - Water Resources Research: 20, 831846, San Francisco (AGU).

Kele, S., Vaselli, O., Szabó, Cs. \& Minissale, A. (2003): Stable isotope geochemistry of Pleistocene travertine from Budakalász (Buda Mts., Hungary). - Acta Geologica Hungarica: 46(2), 16-175, Budapest (Akad. Kiadó).

Kleb, B., Benkovics, L., Gálos, M., Kertész, P., Kocsányi-Kopecskó, K., Marek, I. \& Török, Á. (1993): Engineering geological survey of Rózsadomb area, Budapest, Hungary. - Periodica Politechnica Civil Engineering: 37(4), 261-303.

Leél-Össy, Sz. (1995): A budai Rózsadomb és környékének különleges barlangjai. (The special caves of Buda Rózsadomb and its surroundings) - Földtani Közlöny: 125(3-4), 363-432. (in Hungarian with English abstract) 
Nagymarosy, A. (1987): Buda Mts., Budapest, Mt. Nagy-Hárs, quarry. Geological Institute of Hungary, Excursion Guide: 5 p., Budapest (MÁFI).

Nagymarosy, A. \& Hámor, G. (2012): Genesis and evolution of the Pannonian Basin. - In: Haas, J. (ed.): Geology of Hungary. - Regional Geology Reviews: 149-200, Berlin (Springer).

Pápay, Z. \& Török, Á. (2010): Physical changes of porous Hungarian limestones related to silicic acidester consolidant treatments. - In: Smith, B. J., Gomez-Heras, M., Viles, H. A. \& Cassar, J. (eds) Limestone in the Built Environment: Present-Day Challenges for the Preservation of the Past. Geological Society, London, Special Publications, 331, 147-155.

Popov, Y.A., Pribnow, D.F.C., Sass, J.H., Williams, C.F. \& Burkhardt, H. (1999): Characterization of rock thermal conductivity by high resolution optical scanning. - Geothermics: 28, 253-276, Amsterdam (Elsevier).

Rasser, M.W., Harzhauser, M. (co-ordinators) et al. (2008): Palaeogene and Neogene. - In: McCann, T. (ed.): The Geology of Central Europe. Volume 2: Mesozoic and Cenozoic: 1031-1139, London (Geological Society).

Royden, L.H. (1988): Late Cenozoic tectonics of the Pannonian Basins System. - In: Royden, L. \& Horváth, F. (eds): The Pannonian Basin - a study in basin evolution. American Association of Petroleum Geologists, Memoir: 45, 27-48, Tulsa (AAPG).

Sass, I. \& Götz, A.E. (2012): Characterization of geothermal reservoirs: a thermofacies concept. - Terra Nova: 24, 142-147, Chichester (Wiley). 
Şen, Z. (2002): Drawdown distribution around large diameter well in double porosity medium. - Journal of Hydrologic Engineering: 7, 90-96, Texas (EWRI).

Smith Jr., L.B. \& Davies, G.R. (2006): Structurally controlled hydrothermal alteration of carbonate reservoirs: Introduction. - American Association of Petroleum Geologists, Bulletin: 90, 1635-1640, Tulsa (AAPG).

Török, Á. (2002): Oolitic limestone in polluted atmospheric environment in Budapest: weathering phenomena and alterations in physical properties. - In: Siegesmund, S., Weiss, T.S. \& Vollbrecht, A. (eds), Natural Stones, Weathering Phenomena, Conservation Strategies and Case Studies. Geological Society, London, Special Publications, 205, 363-379.

Török, Á. (2003): Facies analysis and genetic interpretation of travertine, Buda Vár-hegy, Hungary. - Acta Geologica Hungarica: 46(2), 177-193, Budapest (Akad. Kiadó).

Török Á. (2007): Geológia mérnököknek (Geology for Engineers). Műegyetemi Kiadó, Budapest, 384 p. (in Hungarian with English summary)

Török, Á. \& Vásárhelyi, B. (2010): The influence of fabric and water content on selected rock mechanical parameters of travertine, examples from Hungary. - Engineering Geology: 115(3-4), 237-245, Amsterdam (Elsevier). 


\section{Figure captions}

Fig.1: Location map of the study area and medium to high enthalpy areas in western (Zala and Danube basins) and southeastern Hungary (southeastern Great Plain, e.g. Békés Basin). Sedimentary rocks exposed in the Transdanubian Range are located in geothermal prone depth in the Hungarian sub-basins of the Pannonian Basins System. In these areas geothermal power generation is very promising.

Abb. 1: Arbeitsgebiet und Mittel- und Hochenthalpieregionen im Westen (Zala und Donau Becken) und Südosten Ungarns (südöstliche ungarische Ebene, z.B. Békés Becken). Sedimentgesteine, die im transdanubischen Mittelgebirge aufgeschlossen sind, befinden sich in den ungarischen Teilbecken des Pannonischen Beckensystems in Teufen von mehreren Kilometern mit Temperaturen über $120{ }^{\circ} \mathrm{C}$, die eine geothermische Nutzung zur Stromerzeugung ermöglichen.

Fig. 2: Lithostratigraphic units of the Buda Hills, Budapest (Hungary). Abbreviations used: J - Jurassic, C - Cretaceous, P - Palaeocene, Plio.

- Pliocene, Pl. - Pleistocene, Hol. - Holocene.

Abb. 2: Lithostratigraphische Einheiten der Buda Berge, Budapest (Ungarn). Abkürzungen: J - Jura, C - Kreide, P - Paläozän, Plio. - Pliozän, Pl. - Pleistozän, Hol. - Holozän.

Fig. 3: Thermophysical properties (error bars not plotted) of sedimentary reservoir rocks of the Buda Hills (Budapest, Hungary) and thermofacies classification after Sass \& Götz (2012), showing the general geothermal system characterization which depends on the major heat transfer mechanism (convective vs. conductive). 
Abb. 3: Thermophysikalische Eigenschaften (ohne Fehlerbalken dargestellt) sedimentärer Reservoirgesteine der Buda Berge (Budapest, Ungarn) und Thermofazies-Klassifikation nach Sass \& Götz (2012), welche ein geothermisches System in Abhängigkeit vom Wärmetransport (konvektiv/konduktiv) beschreibt.

Table 1. Selected physical parameters of studied rocks (data compiled from Kleb et al. 1993, Hajnal 2002, Görög 2007a, Görög 2007b, Török 2007, Pápay \& Török 2010).

Tabelle 1. Ausgewählte petrophysikalische Eigenschaften der untersuchten Sedimentgesteine (Daten aus Kleb et al. 1993, Hajnal 2002, Görög 2007a, Görög 2007b, Török 2007, Pápay \& Török 2010).

Table 2. Thermophysical parameters (mean values) of investigated sedimentary rocks, Buda Hills.

Tabelle 2. Thermophysikalische Parameter (Mittelwerte) der untersuchten Sedimentgesteine, Buda Berge. 


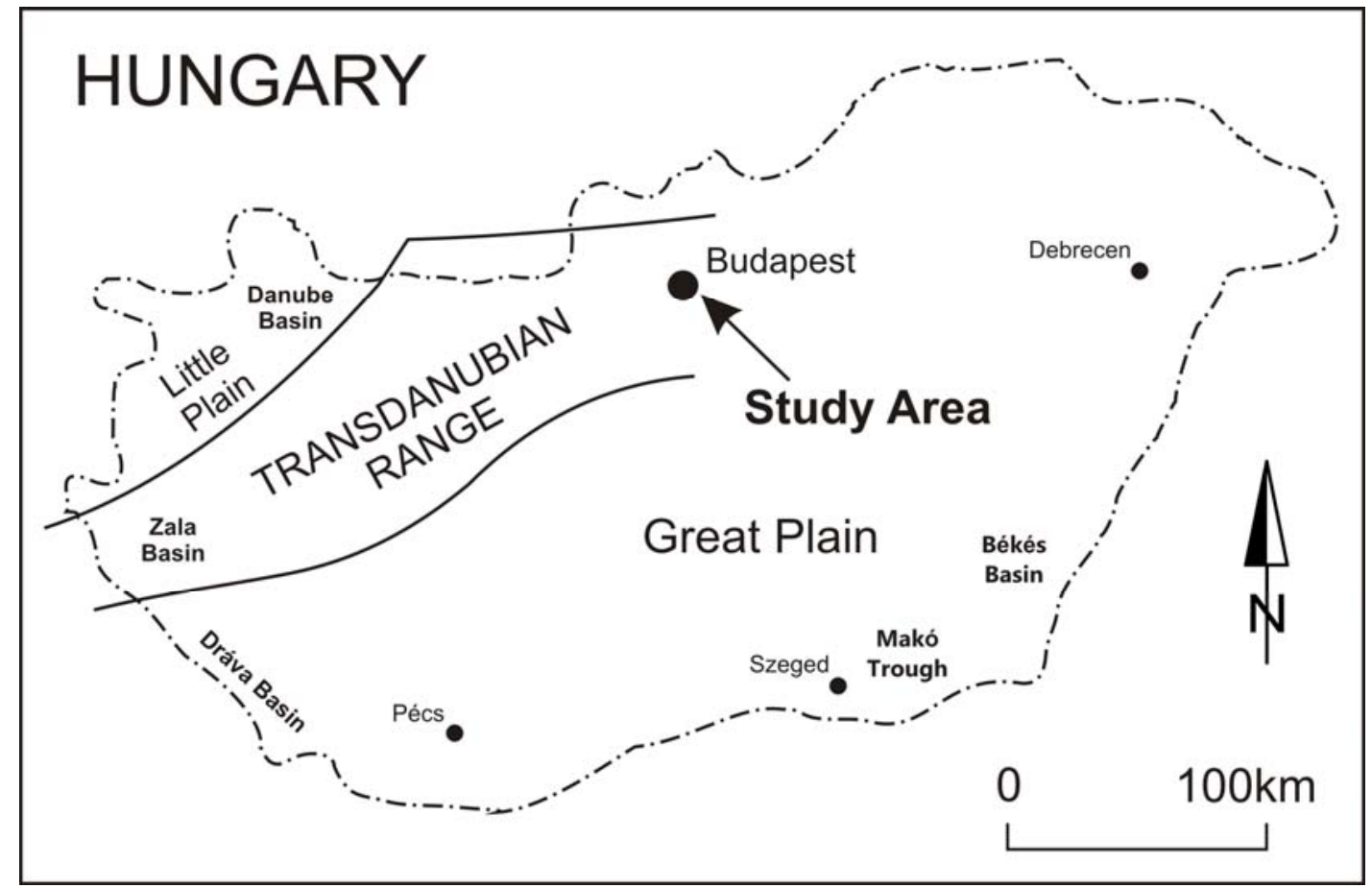

Fig. 1 


\begin{tabular}{|c|c|c|}
\hline 훟ํ & \multicolumn{2}{|c|}{ Travertine } \\
\hline \multirow{2}{*}{$\frac{\dot{0}}{\bar{\alpha}}$} & & \\
\hline & \multicolumn{2}{|c|}{ Travertine } \\
\hline \multirow{5}{*}{$\begin{array}{l}\stackrel{0}{\Xi} \\
\text { d } \\
\stackrel{0}{\Sigma}\end{array}$} & \multirow{2}{*}{\multicolumn{2}{|c|}{ Tinnye Limestone Formation }} \\
\hline & & \\
\hline & \multicolumn{2}{|c|}{ Leitha Limestone Formation } \\
\hline & \multicolumn{2}{|c|}{ 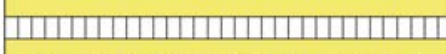 } \\
\hline & \multicolumn{2}{|c|}{ Budafok Sandstone Formation } \\
\hline \multirow{4}{*}{ 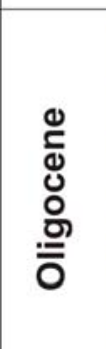 } & \multirow{2}{*}{\multicolumn{2}{|c|}{ Törökbálint Sandstone Formation }} \\
\hline & & \\
\hline & \multicolumn{2}{|c|}{$\begin{array}{l}\text { Hárshegy Kiscell Clay Formation } \\
\text { Sandstone }\end{array}$} \\
\hline & \multicolumn{2}{|c|}{ Tard Clay Formation } \\
\hline \multirow{3}{*}{ 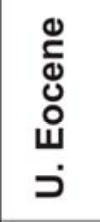 } & \multicolumn{2}{|c|}{ Buda Marl Formation } \\
\hline & \multicolumn{2}{|c|}{$\begin{array}{c}\text { Szépvölgyi } \\
\text { Limestone Formation }\end{array}$} \\
\hline & \multicolumn{2}{|c|}{ Basal Conglomerate } \\
\hline \multicolumn{3}{|l|}{ J. C. P. } \\
\hline \multirow{3}{*}{ 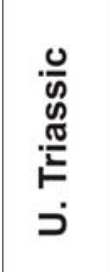 } & $\begin{array}{l}\text { Dachstein } \\
\text { Limestone } \\
\text { Formation }\end{array}$ & \multirow{2}{*}{$\begin{array}{l}\text { Mátyáshegy } \\
\text { Limestone } \\
\text { Formation }\end{array}$} \\
\hline & $\begin{array}{l}\text { Hauptdolomit } \\
\text { Formation }\end{array}$ & \\
\hline & \multicolumn{2}{|c|}{ Budaörs Dolomite Formation } \\
\hline
\end{tabular}

Fig. 2 

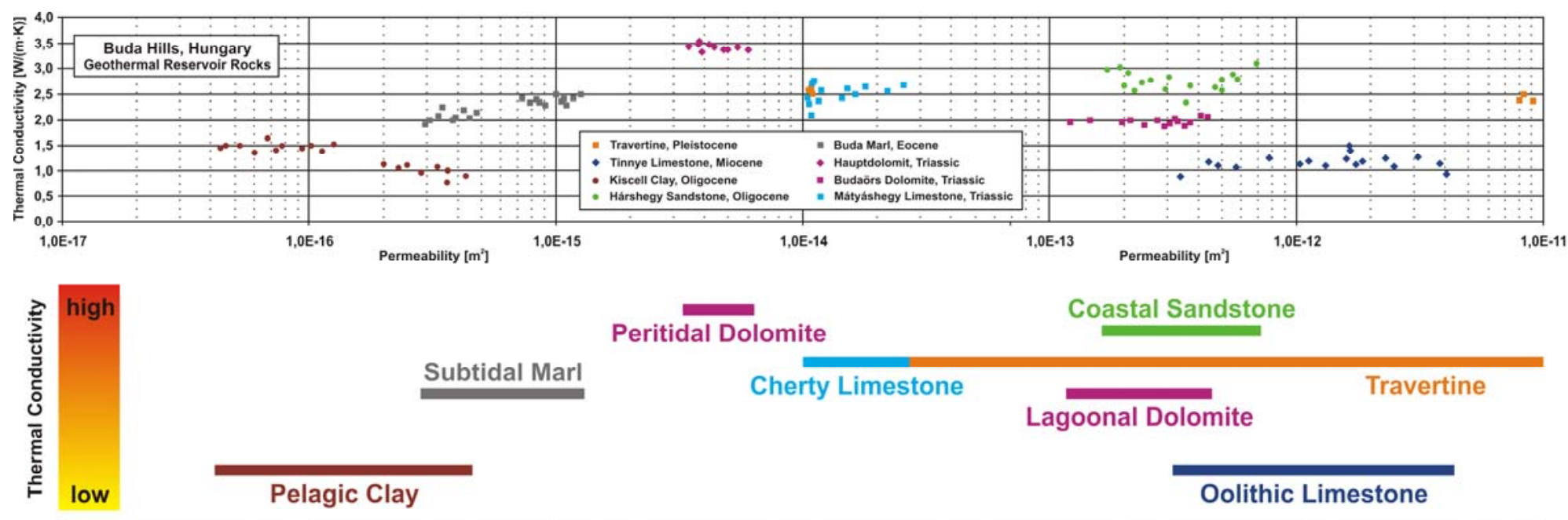

ermeability [m]

1,0E-14

Coastal Sandstone

Peritidal Dolomite

Subtidal Marl

Cherty Limestone

Lagoonal Dolomite

Travertine

$$
\text { 1,0E-17 }
$$

Pelagic Clay

$1,0 \mathrm{E}-14$

$1,0 \mathrm{E}-13$

1,0E-12

$1,0 \mathrm{E}-11$

impermeable

low permeable

permeable

\begin{tabular}{|c|c|c|c|c|}
\hline Petrothermal Systems & & Transitional Systems & & Hydrothermal Systems \\
\hline $\begin{array}{l}\text { Conductive } \\
\text { Heat Transfer }\end{array}$ & $\begin{array}{l}\text { Conductive- } \\
\text { Convective } \\
\text { Heat Transfer }\end{array}$ & $\begin{array}{l}\text { Forced } \\
\text { Convective } \\
\text { Heat Transfer }\end{array}$ & $\begin{array}{l}\text { Auto-Convective - } \\
\text { Forced Convective } \\
\text { Heat Transfer }\end{array}$ & $\begin{array}{l}\text { Auto-Convective } \\
\text { Heat Transfer }\end{array}$ \\
\hline
\end{tabular}

Fig. 3 
Table 1. Selected physical parameters of studied rocks (data compiled from Kleb et al. 1993, Hajnal 2002, Görög 2007a, Görög 2007b, Török 2007, Pápay \& Török 2010)

\begin{tabular}{|c|c|c|c|c|c|c|c|c|}
\hline Lithology & Age & $\begin{array}{l}\text { Apparent } \\
\text { density, } \\
\text { dry } \\
\left(\mathrm{kg} / \mathrm{m}^{3}\right)\end{array}$ & $\begin{array}{c}\text { Apparent } \\
\text { density, water } \\
\text { saturated } \\
\left(\mathrm{kg} / \mathrm{m}^{3}\right)\end{array}$ & $\begin{array}{c}\text { Water } \\
\text { absorption } \\
(\%)\end{array}$ & $\begin{array}{c}\text { Uniaxial } \\
\text { compressive } \\
\text { strength, dry } \\
\text { (MPa) }\end{array}$ & $\begin{array}{c}\text { Uniaxial } \\
\text { compressive } \\
\text { strength, water } \\
\text { saturated (MPa) }\end{array}$ & $\begin{array}{l}\text { Modulus of } \\
\text { elasticity, dry } \\
\text { (MPa) }\end{array}$ & $\begin{array}{c}\text { Modulus of } \\
\text { elasticity, water } \\
\text { saturated (MPa) }\end{array}$ \\
\hline Travertine & Pleistocene & 2348 & 2418 & 11.8 & 28.5 & 15.8 & 1480 & 1140 \\
\hline $\begin{array}{l}\text { Tinnye } \\
\text { Limestone }\end{array}$ & Miocene & 1573 & 1802 & 31.2 & 5.3 & 4.4 & 900 & 500 \\
\hline Kiscell Clay & Oligocene & 1954 & 2189 & - & 1.89 & - & 198 & - \\
\hline $\begin{array}{l}\text { Hárshegy } \\
\text { Sandstone }\end{array}$ & Oligocene & 2190 & 2370 & 8.2 & 51.2 & 38.4 & 9700 & 8200 \\
\hline Buda Marl & Eocene & 2475 & 2564 & 3.5 & 44.9 & 29.1 & 7440 & 6670 \\
\hline Hauptdolomit & Triassic & 2630 & 2688 & 2.2 & 56.0 & 31.0 & 5270 & 4760 \\
\hline $\begin{array}{l}\text { Budaörs } \\
\text { Dolomite }\end{array}$ & Triassic & 2711 & 2776 & 2.4 & 61.6 & - & 8190 & - \\
\hline $\begin{array}{l}\text { Mátyáshegy } \\
\text { Limestone }\end{array}$ & Triassic & 2630 & 2652 & 0.8 & 98.3 & 74.6 & 3240 & 2800 \\
\hline
\end{tabular}


Table 2. Thermophysical parameters (mean values) of studied sedimentary rocks, Buda Hills. -The error is 3 to $5 \%$.

\begin{tabular}{|c|c|c|c|c|c|}
\hline Lithology & Age & $\begin{array}{c}\text { Permeability } \\
{\left[\mathrm{m}^{2}\right]}\end{array}$ & $\begin{array}{c}\text { Thermal } \\
\text { Conductivity } \\
{[\mathrm{W} /(\mathrm{m} \cdot \mathrm{k})]^{*}}\end{array}$ & Location & $\begin{array}{c}\text { Sample } \\
\text { numbers }\end{array}$ \\
\hline \multirow[t]{2}{*}{ Travertine } & \begin{tabular}{|l} 
Pleistocene \\
\end{tabular} & $1.1 \cdot 10^{-14}$ & 2.6 & TV1 & $n=3$ \\
\hline & & $8.4 \cdot 10^{-12}$ & 2.4 & TV2 & $n=3$ \\
\hline \multirow[t]{3}{*}{ Tinnye limestone } & Miocene & $5.8 \cdot 10^{-13}$ & 1.1 & SK1B & $n=5$ \\
\hline & & $3.2 \cdot 10^{-12}$ & 1.2 & SK2C & $n=5$ \\
\hline & & $1.7 \cdot 10^{-12}$ & 1.2 & SK3 & $n=8$ \\
\hline \multirow[t]{2}{*}{ Kiscell Clay } & \begin{tabular}{|l|} 
Oligocene \\
\end{tabular} & $7.9 \cdot 10^{-19}$ & 1.5 & $\overline{\text { KC1 }}$ & $n=11$ \\
\hline & & $3.0 \cdot 10^{-16}$ & 1.0 & KC2 & $n=8$ \\
\hline \multirow[t]{3}{*}{ Hárshegy Sandstone } & \begin{tabular}{|l|} 
Oligocene \\
\end{tabular} & $3.1 \cdot 10^{-13}$ & 2.6 & H1 & $n=5$ \\
\hline & & $5.5 \cdot 10^{-13}$ & 2.8 & H2 & $n=6$ \\
\hline & & $1.9 \cdot 10^{-13}$ & 2.8 & H3 & $n=6$ \\
\hline \multirow[t]{2}{*}{\begin{tabular}{|l|} 
Buda Marl \\
\end{tabular}} & Eocene & $9.0 \cdot 10^{-16}$ & 2.4 & BM1 & $n=11$ \\
\hline & & $3.8 \cdot 10^{-16}$ & 2.2 & BM2 & $n=9$ \\
\hline Hauptdolomit & Triassic & $4.4 \cdot 10^{-15}$ & 3.4 & MD & $n=10$ \\
\hline Budaörs Dolomite & Triassic & $2.9 \cdot 10^{-13}$ & 2.0 & BD & $n=14$ \\
\hline \multirow[t]{2}{*}{ Mátyáshegy Limestone } & \begin{tabular}{|l|} 
Triassic \\
\end{tabular} & $1.3 \cdot 10^{-14}$ & 2.4 & ML1 & $n=7$ \\
\hline & & $1.8 \cdot 10^{-16}$ & 2.5 & ML2 & $n=6$ \\
\hline
\end{tabular}

